\title{
Microvascular Dilatation after Haemodialysis Is Determined by the Volume of Fluid Removed and Fall in Mean Arterial Pressure
}

\author{
Foong Kien Newk-Fon Hey Tow ${ }^{\mathrm{a}}$ Qi Lun Ooi ${ }^{\mathrm{a}}$ Tien Y. Wong ${ }^{\mathrm{b}, \mathrm{c}}$ Ryo Kawasaki ${ }^{\mathrm{b}, \mathrm{d}}$ \\ Deb Colville ${ }^{a}$ Peter Mount ${ }^{\mathrm{e}}$ Judy Savige ${ }^{\mathrm{a}}$ \\ a Department of Medicine (Northern Health), The University of Melbourne, Epping, Vic., and ${ }^{b}$ Centre for \\ Eye Research Australia, The University of Melbourne, Melbourne, Vic., Australia; ' Singapore Eye Research Institute, \\ Yong Loo Lin School of Medicine, National University of Singapore, Singapore; ${ }^{d}$ Department of Ophthalmology

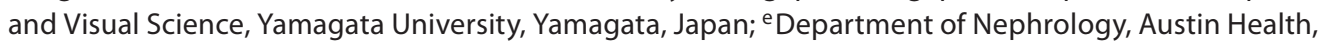 \\ Melbourne, Vic., Australia
}

\section{Key Words}

Dialysis $\cdot$ End-stage renal failure $\cdot$ Microvasculature $\cdot$

Venules $\cdot$ Nitric oxide

\begin{abstract}
Background/Aims: The effects of haemodialysis on the microcirculation are poorly understood. This study examined the changes in small vessel calibre. Methods: 24 patients (including 12 males, median age 62.5 years, range $30-87$ ) underwent digital retinal photography immediately before and after routine haemodialysis. Arteriolar and venular calibres were measured from the images by a trained grader using a highly reproducible, computer-assisted method. $\boldsymbol{R e}$ sults: Patients had an average $2.0 \pm 0.3$ litres of fluid removed with dialysis, and their mean arterial blood pressure fell by $6.8 \mathrm{~mm} \mathrm{Hg}(\mathrm{Cl} 13.8-0.2, \mathrm{p}=0.06)$. Retinal arteriole calibre did not change (mean difference $2.3 \mu \mathrm{m}, \mathrm{Cl}-1.1$ to 5.7, $\mathrm{p}=0.17$ ) but the venules dilated (mean difference $12.7 \mu \mathrm{m}$, $\mathrm{Cl}$ 7.3-18.3, $\mathrm{p}<0.001$ ). Calibre returned to baseline by $2 \mathrm{~h}$. Venules dilated less in diabetics than non-diabetics (mean difference $-6.2 \mu \mathrm{m}, \mathrm{Cl}-9.6$ to $-2.9, \mathrm{p}<0.01$ ). Retinal venular dilatation correlated positively with the volume of fluid removed per kilogramme body weight $(5.9, \mathrm{Cl} 0.2-11.5, \mathrm{p}=$ 0.04 ), and negatively with the fall in mean arterial pressure
\end{abstract}

$(-0.36, \mathrm{Cl}-0.72$ to $-0.01, \mathrm{p}<0.05)$ after adjusting for age, gender, diabetes and dyslipidaemia. Conclusion: Haemodialysis is associated with systemic venular dilatation.

Copyright $\odot 2012$ S. Karger AG, Basel

\section{Introduction}

Individuals with chronic kidney disease have an increased risk of macrovascular disease, and dialysis patients have a cardiovascular mortality that is 20 times greater than in those with normal renal function [1]. Microvascular disease is also increased in renal failure, and contributes to the greater likelihood of heart failure, stroke, dementia, and progressive renal impairment [27]. In renal failure, both 'traditional' risk factors, such as hypertension and dyslipidaemia, and 'non-traditional' factors, including inflammation, endothelial damage and disturbed calcium-phosphate homeostasis, are believed responsible for the increase in vascular events [8].

The systemic microvasculature can be assessed in vivo by direct examination of the retinal vessels [9]. Retinal changes in microvascular disease include focal and generalised arteriolar narrowing, arteriovenous nicking, haemorrhage and exudates [10-12]. Specialised methods 
use quantitative computer-based techniques to measure retinal vessel calibre directly from digital images [13-15], or indirectly, from blood flow using Doppler ultrasonography $[16,17]$. Changes in vessel branching patterns or 'fractals' that reflect ischemia can also be assessed from digitised retinal images $[18,19]$.

Patients with renal failure typically have a microvasculature that is damaged by hypertension and dyslipidaemia, and possibly by diabetes and smoking [20-22]. Arterioles become narrower with increasing age, hypertension and atherosclerosis [22]. Venules dilate with systemic inflammation, diabetes, obesity, smoking and dyslipidaemia [23-27]. Both arterioles and venules are narrowed in renal failure, and the more severe the renal failure, the smaller the vessel diameter [28]. However, microvascular calibre is also dynamic, and may be affected by fluid status and vasoactive stimuli $[16,17]$, but not, in population-based surveys, by commonly-used medications [29].

Patients with end-stage kidney disease who are haemodialysed undergo fluctuations in their fluid status, and levels of electrolytes and uremic toxins, during treatment. Dialysis is sometimes associated with hypotension, headache, nausea, muscle cramps and cardiac ischemia, and while the mechanisms are incompletely understood, changes in the microvascular blood flow have been demonstrated $[16,17]$.

This study examined the direct effect of dialysis on the calibre of the retinal, and hence systemic, microvasculature and the major determinants of these changes.

\section{Subjects and Methods}

Study Participants

Patients undergoing morning haemodialysis 3 times weekly, and 2 days after their previous treatment, at a major metropolitan centre were approached to take part in this study. The only patients who were excluded were those in whom the retina could not be visualised, usually because of cataracts. Haemodialysis was performed using Gambro machines (AK200S; Gambro, Sydney, N.S.W., Australia), $\mathrm{HCO}_{3}$-based dialysate, at $37^{\circ} \mathrm{C}$, ultrapure water and synthetic biocompatible dialysers (Polyflux H; Gambro). Blood flow rates ranged from 200 to $400 \mathrm{ml} / \mathrm{min}$, and ultrafiltration varied according to individual prescription. Anticoagulation was achieved with a 1,000-unit intravenous heparin bolus followed by a 500 - to 1,000 -unit/h infusion.

Patient medical details, as well as their pre- and post-dialysis weights, and systolic and diastolic blood pressures were recorded.

\section{Retinal Imaging and Grading}

Digital retinal imaging was performed before and immediately after dialysis. Photographs centred on the optic discs of both eyes were recorded with a Canon CR5 non-mydriatic retinal camera (Canon, Japan). Retinal vascular calibre was measured using a computer-assisted system (University of Wisconsin, Madison, Wisc., USA) by a trained grader who was masked to participant characteristics [30]. Briefly, all vessels coursing through a zone $0.5-1.0$ disc diameters from the disc margin were measured using a computer imaging program (IVAN; University of Wisconsin). Measurements were summarised as the central retinal artery and vein equivalents (CRAE and CRVE, respectively) using the formulae proposed by Knudtson et al. [31]. This method was highly reproducible with intra-class correlation coefficients for CRAE and CRVE of 0.986 and 0.989 , respectively.

In addition, CRAE and CRVE were studied pre- and 0, 1,2 and $18 \mathrm{~h}$ post-dialysis in 8 eyes ( 2 male and 6 female).

\section{Statistical Analysis}

Continuous variables were compared with Student's t test and dichotomous variables with Fisher's exact test. The CRAE and CRVE before and after dialysis were compared with Student's paired t test. The effect of the volume of fluid removed per kilogramme body weight and the number of years on dialysis on the change in vessel calibre were measured with Pearson's correlation coefficient. The determinants of the change in CRAE and CRVE with dialysis were examined in multiple linear regression analysis.

A result was considered significant if the $95 \%$ confidence interval did not include 1.00 , and the $p$ value was $<0.05$. Statistical analyses were performed using Stata version 10 software (Stata Corp., College Station, Tex., USA).

This study conformed with the Declaration of Helsinki, and was approved by the Human Research Ethics Committees of Austin Health and Northern Health, and all participants provided written, informed consent.

\section{Results}

\section{Characteristics of Participants}

Twenty-four patients (12 males) with a median age of 62.5 years (range $30-87$ ) were studied. They had endstage kidney disease from diabetic nephropathy $(n=8$, $33 \%)$, glomerulonephritis $(\mathrm{n}=4,17 \%)$, renovascular disease $(n=5,21 \%)$, reflux nephropathy $(n=2,8 \%)$, or from surgery, trauma or nephrotoxic medication $(n=5,21 \%)$. Five $(21 \%)$ had previously undergone renal transplantation and, overall, they had spent a median of 4.5 years continuously (range $0.2-34$ ) on dialysis until now.

Twenty patients $(83 \%)$ had treated hypertension (systolic/diastolic blood pressure $\geq 140 / 90 \mathrm{~mm} \mathrm{Hg}$ ), 10 (42\%) had diabetes, 18 (75\%) had dyslipidaemia, and, while none smoked currently, 11 (46\%) were ex-smokers. Seven (29\%) were currently treated with vasodilators (isordil, prazosin or hydralazine) and 1 (4\%) with an angiotensinconverting enzyme inhibitor. 


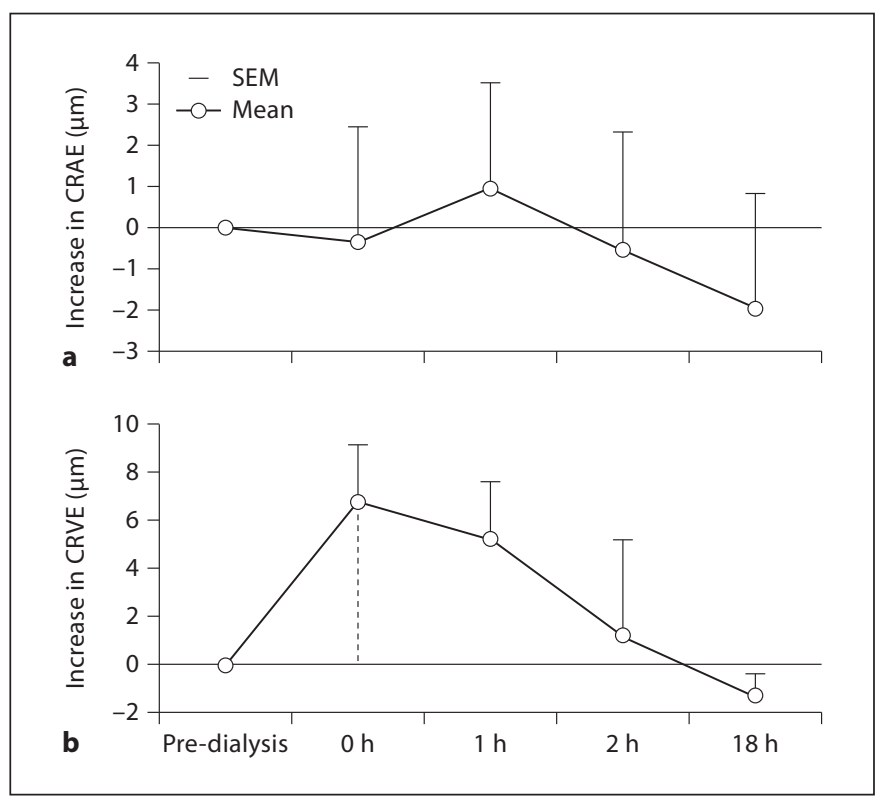

Fig. 1. Time course of CRAE (a) and CRVE (b) with dialysis.

Table 1. Changes with dialysis in all patients

\begin{tabular}{|c|c|c|c|}
\hline \multirow[t]{2}{*}{ Criteria } & \multicolumn{2}{|c|}{ All dialysis patients $(\mathrm{n}=24)$} & \multirow{2}{*}{$\begin{array}{l}\mathrm{p} \text { value } \\
\text { mean difference } \\
(95 \% \mathrm{CI})\end{array}$} \\
\hline & pre-dialysis & post-dialysis & \\
\hline Weight, kg & $77.4 \pm 17.0$ & $75.4 \pm 16.9$ & $\begin{array}{l}<0.001 \\
-2.0(-2.3 \text { to }-1.6)\end{array}$ \\
\hline $\begin{array}{l}\text { Systolic BP } \\
\mathrm{mm} \mathrm{Hg}\end{array}$ & $137.0 \pm 20.5$ & $125.5 \pm 19.4$ & $\begin{array}{r}0.03 \\
-11.5(-22.0 \text { to }-0.9) \\
\end{array}$ \\
\hline $\begin{array}{l}\text { Diastolic BP } \\
\mathrm{mm} \mathrm{Hg}\end{array}$ & $68.8 \pm 16.2$ & $64.4 \pm 13.7$ & $\begin{array}{l}0.24 \\
-4.4(-11.9 \text { to } 3.1)\end{array}$ \\
\hline $\begin{array}{l}\text { Mean arterial } \\
\text { pressure } \\
\text { mm Hg }\end{array}$ & $91.5 \pm 13.4$ & $84.7 \pm 11.5$ & $\begin{array}{l}0.06 \\
-6.8(-13.8 \text { to } 0.2)\end{array}$ \\
\hline CRAE, $\mu \mathrm{m}$ & $144.6 \pm 13.0$ & $146.9 \pm 12.8$ & $\begin{array}{l}0.17 \\
2.3(-1.1 \text { to } 5.7)\end{array}$ \\
\hline CRVE, $\mu \mathrm{m}$ & $209.2 \pm 24.3$ & $221.9 \pm 22.3$ & $\begin{array}{l}0.001 \\
12.7(7.3-18.0)\end{array}$ \\
\hline
\end{tabular}

\section{Systemic Changes with Dialysis}

Immediately after dialysis, the patients' mean body weight fell from $77.4 \pm 17.0$ to $75.4 \pm 16.9 \mathrm{~kg}$ which represented $2.6 \pm 1.1 \%$ of their total weight (difference -2.0 $\mathrm{kg}, \mathrm{CI}-2.3$ to $-1.6, \mathrm{p}<0.001$ ) (table 1 ). Their mean arterial blood pressure fell from $91.5 \pm 13.4$ to $84.7 \pm 11.5$ $\mathrm{mm} \mathrm{Hg}$ (difference $-6.8 \mathrm{~mm} \mathrm{Hg}, \mathrm{CI}-13.8$ to $0.2, \mathrm{p}=0.06$ ), and their mean systolic (difference $-11.5 \mathrm{~mm} \mathrm{Hg}$, CI -22.0 to $-0.9, \mathrm{p}=0.03$ ), but not diastolic, blood pressures fell significantly. However, none of these patients was symptomatic from the fluid removal or fall in blood pressure.

\section{Retinal Vascular Calibre}

The patients' mean CRAE did not change significantly after dialysis $(144.6 \pm 13.0$ and $146.9 \pm 12.8 \mu \mathrm{m}$, difference 2.3 , CI -1.1 to $5.7, \mathrm{p}=0.17$ ). However, their mean CRVE increased from $209.2 \pm 24.3$ to $221.9 \pm 22.3 \mu \mathrm{m}$ (difference 12.7, CI 7.3-18.0, $\mathrm{p}<0.001$ ) (table 1). The CRVE was maximal immediately after dialysis and returned to baseline by $2 \mathrm{~h}$ (fig. 1 ).

Determinants of the Increase in CRVE after Dialysis

After dialysis, the CRVE increased in both males and females $(17.9 \mu \mathrm{m}$, CI 9.6-21.2, $\mathrm{p}=0.001$, and $7.4 \mu \mathrm{m}, \mathrm{CI}$ $0.8-14.0, \mathrm{p}=0.03$, respectively), but the increase was greater in males (difference $10.4 \mu \mathrm{m}$, CI 7.8-13.1, $\mathrm{p}<0.001)$.

Prior to dialysis, the CRVE was also not different between diabetics and non-diabetics (211.4 \pm 25.4 and $207.7 \pm 24.3 \mu \mathrm{m}$, respectively, difference $3.7 \mu \mathrm{m}$, CI -17.6 to $25.0, \mathrm{p}=0.7)$. After dialysis, the CRVE increased in both diabetics $(9.0 \mu \mathrm{m}, \mathrm{CI} 0.8-17.3, \mathrm{p}=0.04)$ and nondiabetics $(15.3 \mu \mathrm{m}$, CI 7.6-22.9, $\mathrm{p}=0.001)$ but the increase was less in diabetics (difference $-6.2 \mu \mathrm{m}, \mathrm{CI}-9.6$ to -2.9 , $\mathrm{p}=0.001$ ).

After dialysis, the change in CRVE correlated with the volume of fluid removed per kilogramme body weight (Pearson's correlation coefficient $0.41, \mathrm{p}=0.04$ ) (fig. 2). There was no correlation with the years spent on dialysis (Pearson's correlation coefficient $0.07, \mathrm{p}=0.75$ ).

\section{Independent Determinants of the Increase in CRVE after Dialysis}

The increase in CRVE after dialysis was determined by the volume of fluid removed per kilogramme body weight (5.87, CI $0.0-11.5, \mathrm{p}=0.04)$ and the fall in mean arterial pressure $(-0.36, \mathrm{CI}-0.7$ to $0.0, \mathrm{p}=0.46)$ after adjusting for age, gender, diabetes, and dyslipidaemia (table 2).

\section{Discussion}

The major findings of this study were that dialysis resulted in dilatation of the retinal venules, and that the dilatation was short-lived. When all possible variables were taken into account, the major determinants of venular dilatation post- dialysis were the volume of fluid removed and the fall in mean arterial pressure. 
Although the CRVE after dialysis appeared to increase more in males than females, and less in diabetics than non-diabetics, gender and diabetes were not independent determinants of dilatation. Patients with diabetes typically have larger retinal venules than non-diabetics [26], even in renal failure [28]. In this study, venules in diabetics were only marginally larger than in non-diabetics, and dilated less after dialysis suggesting either that these vessels were already maximally dilated or that they were damaged and less responsive to further stimuli. The more pronounced dilatation in males may have been because fewer were diabetic and because they had more fluid removed.

The major strengths of this study were that it examined a cohort of well-characterized patients who underwent routine dialysis in the same unit contemporaneously. It also used highly reproducible methods to assess changes in retinal vessel calibre. The study's limitations were that the cohort was small, clinically heterogeneous, and included many diabetics, and that the volume of fluid removed varied in individual patients. This nevertheless probably represents a typical cohort for many dialysis units.

Dilatation of the retinal microvasculature after dialysis is thought to occur secondary to the release of vasoactive factors, such as nitric oxide, in response to the reduced intravascular volume [32]. For example, asymmetric dimethylarginine, an inhibitor of nitric oxide synthase, accumulates in renal failure [33,34], but is removed by dialysis, resulting in enhanced nitric oxide activity and consequent vasodilatation.

Retinal vasodilation reflects systemic changes that mainly affect the capacitance vessels in the bowel and periphery and probably contribute to the hypotension, headache, nausea, muscle cramps and myocardial ischemia that may result from the removal of large volumes of fluid. The time course of post-dialysis venular vasodilation demonstrated here that it was short-lived and that calibre returned to baseline by about $2 \mathrm{~h}$ which was consistent with the half-life of the putative vasoactive factors.

Retinal venular dilatation has been described previously after dialysis using colour Doppler ultrasonography and laser Doppler velocimetry $[16,17]$, but our study measured vessel calibre directly, and assessed the determinants of the vasodilation. Microvascular grading is convenient because it does not require the use of special equipment but only access to a vascular calibre grading centre.

The present study did not demonstrate any change in arteriolar size after dialysis, although generally, arteriole calibre changes in parallel with venular calibre but to a lesser extent.

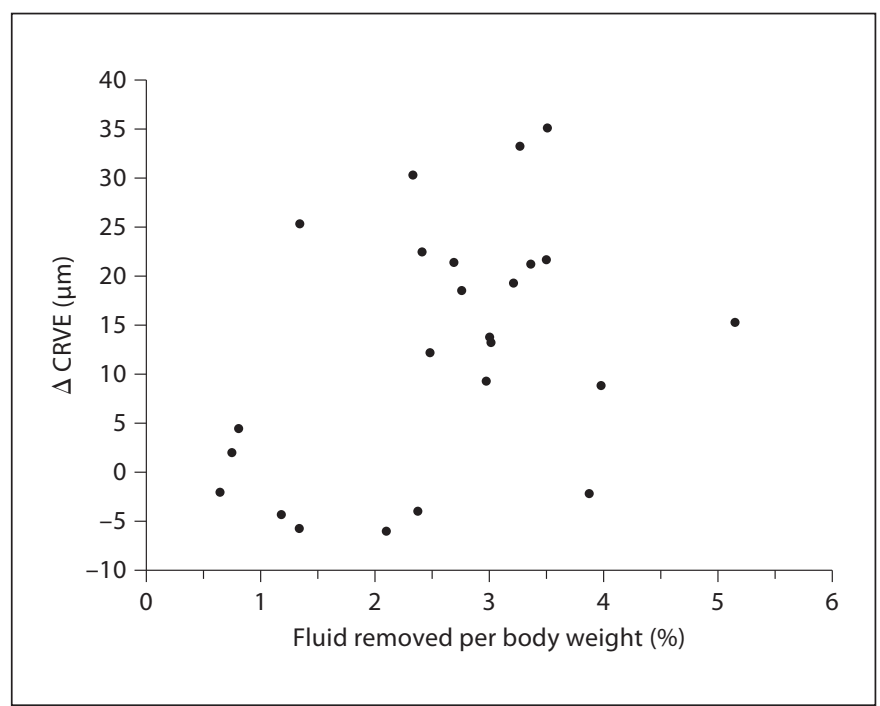

Fig. 2. Change in CRVE with fluid removed per kilogramme body weight.

Table 2. Determinants of CRVE change

\begin{tabular}{lccc}
\hline Criteria & \multicolumn{2}{c}{ Difference in CRVE } & \multirow{2}{*}{ p value } \\
\cline { 2 - 3 } & coefficient & $95 \%$ CI & \\
\hline Age & 0.15 & -0.2 to 0.5 & 0.37 \\
$\begin{array}{l}\text { Gender } \\
\text { Diabetes }\end{array}$ & 2.24 & -10.4 to 14.91 & 0.71 \\
$\begin{array}{l}\text { Dyslipidaemia } \\
\text { Volume removed per }\end{array}$ & -4.06 & -15.6 to 7.5 & 0.47 \\
$\quad$ kg body weight & 5.87 & -19.6 to 4.8 & 0.22 \\
$\begin{array}{l}\text { Difference in mean } \\
\quad \text { arterial pressure }\end{array}$ & -0.36 & $-0.2-11.5$ & $0.04^{*}$ \\
Constant & -8.48 & -31.2 to 14.3 & 0.44 \\
\hline
\end{tabular}

Prob $>\mathrm{F}=0.04$

* = p significant.

Studies in other populations have found that retinal venular dilatation predicts an increased risk of cardiac disease or stroke $[35,36]$, but the dilatation seen after dialysis is transient and serves to improve the local blood supply, while also contributing to dialysis-associated hypotension.

The retinal microvasculature represents a model system in which to further examine dialysis-induced venular dilatation. 


\section{Acknowledgements}

We would like to thank the many patients who took part in these studies. This work was published as an abstract in the abstract book of the American Society of Nephrology Annual Meeting, November 2010.

\section{Disclosure Statement}

The authors have no support or financial disclosures to declare. F.K.N.-F.H.T. and Q.L.O. were medical students who undertook this research as part of their B Biomedical Science studies. The results described here have not been published previously in whole or part except in abstract format.

\section{References}

$\checkmark 1$ Bloembergen W: Cardiac disease in chronic uremia: epidemiology. Adv Ren Replace Ther 1997;4:185-193.

-2 Amann K, Ritz E: Microvascular disease - the Cinderella of uraemic heart disease. Nephrol Dial Transplant 2010;15:1493-1503.

>3 Khatri M, Wright CB, Nickolas TL, Yoshita M, Paik MC, Kranwinkel G, Sacco RL, DeCarli C: Chronic kidney disease is associated with white matter hyperintensity volume the Northern Manhattan Study (NOMAS). Stroke 2007;38:3121-3126.

$\checkmark 4$ Wada M, Nagasawa H, Iseki C, Takahashi Y, Sato H, Arawaka S, Kawanami T, Kurita K, Daimon M, Kato T: Cerebral small vessel disease and chronic kidney disease: results of a cross-sectional study in community-based Japanese elderly. J Neurol Sci 2008;272:3642.

5 Murray AM: Cognitive impairment in the aging dialysis and chronic kidney disease populations: an occult burden. Adv Chronic Kidney Dis 2008;15:123-132.

6 Kang DH, Kanellis J, Hugo C, Truong L, Anderson S, Kerjaschki D, Schreiner GF, Johnson RJ: Role of the microvascular endotheli$\mathrm{um}$ in progressive renal disease. J Am Soc Nephrol 2002;13:806-816.

-7 Nakagawa T, Kang DH, Ohashi R, Suga S, Herrera-Acosta J, Rodriguez-Iturbe B, Johnson RJ: Tubulointerstitial disease: role of ischemia and microvascular disease. Curr Opin Nephrol Hypertension 2003;12:233-241.

$>8$ Van der Zee S, Baber U, Elmariah S, Winston J, Fuster V: Cardiovascular risk factors in patients with chronic kidney disease. Nat Rev Cardiol 2009;6:580-589.

$\checkmark 9$ Thompson CS, Hakim AM: Living beyond our physiological means small vessel disease of the brain is an expression of a systemic failure in arteriolar function: a unifying hypothesis. Stroke 2009;40:E322-E330.

-10 Sharrett AR, Hubbard LD, Cooper LS, Sorlie PD, Brothers RJ, Nieto FJ, Pinsky JL, Klein R: Retinal arteriolar diameters and elevated blood pressure - the Atherosclerosis Risk In Communities Study. Am J Epidemiol 1999; 150:263-270.

$>11$ Wong T, Mitchell P: The eye in hypertension. Lancet 2007;369:425-435.

12 Harnish A, Pearce ML: Evolution of hypertensive retinal vascular-disease - correlation between clinical and postmortem observations. Medicine 1973;52:483-533.

$\checkmark 13$ Hubbard LD, Brothers RJ, King WN, Clegg LX, Klein R, Cooper LS, Sharrett AR, Davis MD, Cai JW: Methods for evaluation of reti- nal microvascular abnormalities associated with hypertension/sclerosis in the Atherosclerosis Risk In Communities Study. Ophthalmology 1999;106:2269-2280.

14 Liew G, Wang JJ, Mitchell P, Wong TY: Retinal vascular imaging a new tool in microvascular disease research. Circ Cardiovasc Imaging 2008;1:156-161.

15 Sun C, Wang JJ, Mackey DA, Wong TY: Retinal vascular calibre: systemic, environmental, and genetic associations. Surv Ophthalmol 2009;54:74-95.

16 Nagaoka T, Takeyama Y, Kanagawa S, Sakagami K, Mori F, Yochida A: Effect of haemodialysis on retinal circulation in patients with end-stage renal disease. Br J Ophthalmol 2004;88:1026-1029.

17 Tosun O, Davutluoglu B, Arda K, Boran M, Yarangumeli A, Kurt A, Ozkan D: Determination of the effect of a single haemodialysis session on retrobulbar blood haemodynamics by colour Doppler ultrasonography. Acta Radiol 2007;48:764-767.

18 Mainster MA: The fractal properties of retinal vessels: embryological and clinical implications. Eye 1990;4:235-241.

19 Family F, Masters BR, Platt DE: Fractal pattern formation in human retinal vessels. Physica D 1989;38:98-103.

20 Vrabec R, Vatavuk Z, Pavolovic D, Sesar A, Cala S, Mandic K, Bucan K: Ocular findings in patients with chronic renal failure undergoing haemodialysis. Coll Antropol 2005; 29(suppl 1):95-98.

21 Evans RD, Rosner M: Ocular abnormalities associated with advanced kidney disease and haemodialysis. Semin Dial 2005; 18:252-257.

22 Wong TY, Coresh J, Klein R, Muntner P, Couper DJ, Sharrett AR, Klein BEK, Heiss G, Hubbard LD, Duncan BB: Retinal microvascular abnormalities and renal dysfunction: the Atherosclerosis Risk in Communities Study. J Am Soc Nephrol 2004;15:2469-2476.

23 Klein R, Klein BEK, Knudtson MD, Wong TY, Tsai MY: Are inflammatory factors related to retinal vessel calibre? The Beaver Dam Eye Study. Arch Ophthalmol 2006;124:87-94.

-24 Wong TY, Duncan BB, Golden SH, Klein R, Couper DJ, Klein BEK, Hubbard LD, Sharrett AR, Schmidt MI: Associations between the metabolic syndrome and retinal microvascular signs: the Atherosclerosis Risk in Communities Study. Invest Ophthalmol Vis Sci 2004; 45:2949-2954.

25 Wong TY, Islam FMA, Klein R, Klein BEK, Cotch MF, Castro C, Sharrett AR, Shahar E: Retinal vascular calibre, cardiovascular risk factors, and inflammation: the Multi-Ethnic Study of Atherosclerosis (MESA). Invest Ophthalmol Vis Sci 2006;47:2341-2350.

-26 Klein R, Klein BEK, Moss SE, Wong TY, Sharrett AR: Retinal vascular calibre in persons with type 2 diabetes - the Wisconsin Epidemiological Study of Diabetic Retinopathy. Ophthalmology 2006;113:1488-1498.

27 Kifley A, Liew G, Wang JJ, Kaushik S, Smith W, Wong TY, Mitchell P: Long-term effects of smoking on retinal microvascular calibre. Am J Epidemiol 2007;166:1288-1297.

28 Ooi QL, Tow FK, Deva R, Alias MA, Kawasaki R, Wong TY, Mohamad N, Colville D, Hutchinson A, Savige J: The microvasculature in chronic kidney disease. Clin J Am Soc Nephrol 2011;6:1872-1878.

29 Wong TY, Knudtson MD, Klein BEK, Klein R, Hubbard LD: Medication use and retinal vessel diameters. Am J Ophthalmol 2005;139: 373-375.

-30 Wong TY, Knudtson MD, Klein R, Klein BEK, Meuer SM, Hubbard LD: Computer-assisted measurement of retinal vessel diameters in the Beaver Dam Eye Study - methodology, correlation between eyes, and effect of refractive errors. Ophthalmology 2004;111:11831190.

31 Knudtson MD, Lee KE, Hubbard LD, Wong TY, Klein R, Klein BEK: Revised formulas for summarizing retinal vessel diameters. Curr Eye Res 2003;27:143-149.

32 Noris M, Benigni A, Boccardo P, Aiello S, Gaspari F, Todeschini M, Figliuzzi M, Remuzzi G: Enhanced nitric oxide synthesis in uremia: implications for platelet dysfunction and dialysis hypotension. Kidney Int 1993;44: 445-450.

33 Ritz E, Vallance P, Nowicki M: The effect of malnutrition on cardiovascular mortality in dialysis patients: is L-arginine the answer? Nephrol Dial Transplant 1994;9:129-305.

34 Kang ES, Tevlin MT, Wang YB, Chiang TM, Cardenas R, Myers LK, Acciardo SR: Haemodialysis hypotension: interaction of inhibitors, iNOS, and the interdialytic period. Am J Med Sci 1999;317:9-21.

35 Wong TY, Kamineni A, Klein R, Sharrett AR, Klein BE, Siscovick DS, Cuchman M, Duncan BB: Quantitative retinal venular calibre and risk of cardiovascular disease in older persons. Arch Intern Med 2006;166:2388-2394.

36 Ikram MK, de Jong FJ, van Dijk EJ, Prins ND, Hofman A, Breteler MMB, de Jong PTVM: Retinal vessel diameters and cerebral small vessel disease: the Rotterdam Scan Study. Brain 2006;129:182-188. 